\title{
Breeding for organic dairy farming: what types of cows are needed?
}

\section{Invited Review}

Cite this article: Rodríguez-Bermúdez $\mathrm{R}$, Miranda M, Baudracco J, Fouz R, Pereira V and López-Alonso M (2019). Breeding for organic dairy farming: what types of cows are needed? Journal of Dairy Research 86, 3-12. https:// doi.org/10.1017/S0022029919000141

Received: 28 May 2018

Revised: 12 August 2018

Accepted: 25 January 2019

\section{Keywords:}

dairy cattle; organic farming; dairy breeds; Holstein-Friesian; crosses

Author for correspondence:

Marta López-Alonso,

Email: marta.lopez.alonso@usc.es (c) Hannah Dairy Research Foundation 2019

\section{CAMBRIDGE UNIVERSITY PRESS}

Ruth Rodríguez-Bermúdez ${ }^{1}$, Marta Miranda², Javier Baudracco ${ }^{3}$, Ramiro Fouz ${ }^{4}$, Victor Pereira ${ }^{1}$ and Marta López-Alonso ${ }^{1}$

${ }^{1}$ Departamento de Patoloxía Animal, Facultade de Veterinaria, Universidade de Santiago de Compostela, 27002 Lugo, Spain; ${ }^{2}$ Departamento de Anatomía, Produción Animal e Ciencias Clínicas Veterinarias, Facultade de Veterinaria, Universidade de Santiago de Compostela, 27002 Lugo, Spain; ${ }^{3}$ Facultad de Ciencias Agrarias, Universidad Nacional del Litoral, Esperanza, Santa Fe, Argentina and ${ }^{4}$ Africor Lugo, Ronda de Fingoi, Lugo, Spain

\begin{abstract}
Organic farming is believed by many to be an environmentally friendly production system that promotes the use of local forage while strongly limiting the input of chemicals, including allopathic treatments. As organic dairy farming has grown, farmers have realised that many available conventional breeds of cow are not well adapted to the new situations and that more 'robust' cows, able to function well in the constraining organic environment, are needed to yield acceptable longevity and productivity. In this review paper, the current breed diversity in organic dairy farming is analysed with the aim of identifying the types of cow that would best fulfil organic breeding goals. Unlike the conventional sector, organic dairy farming is very heterogeneous and no single type of cow can adapt well to all scenarios. There are advantages and disadvantages to the use of existing breeds (rustic Holstein-Friesian, other rustic breeds and crosses), and strong genotype $\times$ environment interactions demand different strategies for very diverse situations. Organic dairy farms producing milk for systems that recompense milk volume would benefit from using higher milk yielding cows, and rustic Holstein-Friesian cows may be the best option in such cases. Although most Holstein-Friesian cows are currently selected for use in conventional systems, this situation could be reversed by the implementation of an organic merit index that includes organic breeding goals. Farms producing milk either for systems that recompense milk solids or for transformation into dairy products would benefit from using breeds other than Holstein-Friesian or their crosses. Organic farmers who focus on rural tourism, farm schools or other businesses in which marketing strategies must be taken into account could benefit from using local breeds (when possible) or other rustic breeds that are highly valued by consumers.
\end{abstract}

Organic agriculture emerged as a reaction to the industrialisation of agriculture and its associated environmental and social problems (Röös et al., 2018). Organic livestock production focuses predominantly on forage-based systems, with emphasis on improving animal health and welfare, while reducing the use of conventional veterinary treatments, prophylactic drugs, chemical fertilisers and pesticides (Rozzi et al., 2007; Van Diepen et al., 2007; Ahlman et al., 2011; Horn et al., 2012). Together, these factors make organic systems highly dependent on the environment, and a more holistic view of the farming system is required in order to achieve adequate productivity and resilience (Gouttenoire et al., 2013).

In the European Union (EU), organic livestock production is considered in Council regulation (EC) No 834/2007 and Commission regulation (EU) No 889/2008, which establish that animals on organic farms should (whenever possible) have access to open air or grazing areas, respect animal welfare, restrict the number of medical treatments, and strongly limit the use of chemically synthesised products (Table 1). In relation to livestock, the Commission regulation specifically states that 'In the choice of breeds account shall be taken of the capacity of animals to adapt to local conditions, their vitality and their resistance to disease or health problems'. Despite these recommendations, little effort has been made to produce animals that are well adapted to organic conditions, and most dairy farmers maintain the same livestock upon converting to organic systems. In fact, with few exceptions, dairy cattle on organic farms are still selected on the basis of information about conventional systems. Recent studies estimate that the main challenge for sustainable organic and low-input dairy farming is to identify genotypes that are best adapted to forage-based production systems (Peeters and Wezel, 2017). Moreover, in the last few years both critics and proponents of organic agriculture have concluded that yields in organic agriculture must increase (Röös et al., 2018). This increase is necessary not only to feed a growing, more affluent global population but also so that organic farms will become more 'environmentally efficient'. However, breeding for higher yields has 
Table 1. Summary of EU regulations concerning organic dairy farming (Commission Regulation EC, 2008)

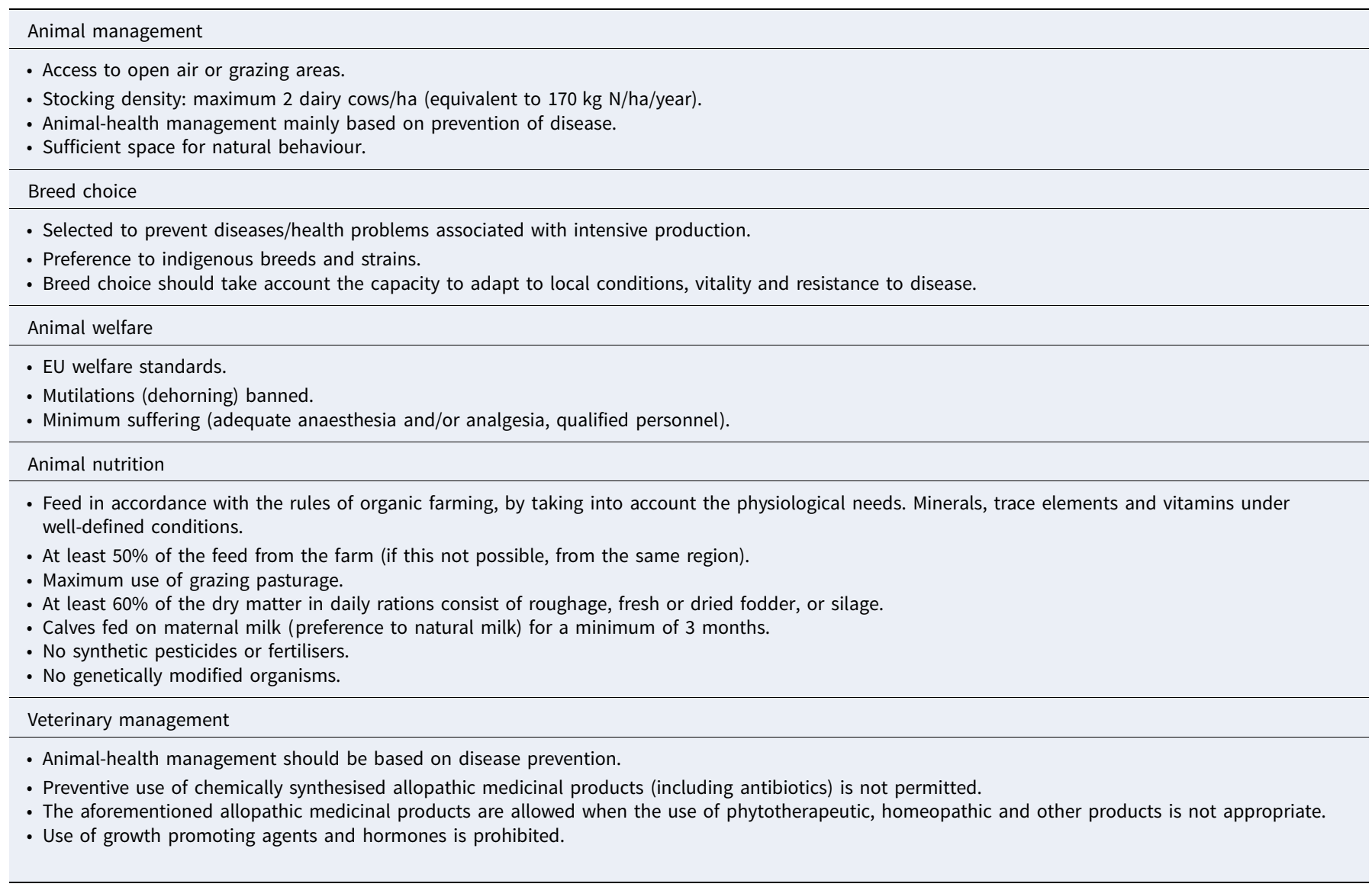

the risk of producing less robust animals with potential health problems, including low fertility (Röös et al., 2018).

It is well known that during the last half of the $20^{\text {th }}$ century, genetic selection of dairy cattle mainly focused on the Holstein-Friesian breed to improve milk production. The resulting cow can be considered a high maintenance animal for use in extremely standardised intensive systems. However, the environment in organic production systems is very different, mainly with regard to feeding regimes and medical treatments (Ahlman, 2010). The selection process has also resulted in reduced reproductive efficiency, extended calving intervals, increased health problems, increased culling rates and decreased productive life (Bluhm, 2009), especially when these highly selected cows are reared outside of intensive nutritional and environmental management systems. Thus, highly productive Holstein-Friesian cattle could show a limited capacity to adapt to the low-input diets on organic farms, resulting in low longevity (Kolver, 2003) and productive performance (Van Diepen et al., 2007).

In this context, as organic dairy farming has grown in Europe, farmers have realised that the available conventional cows are not well adapted to the new organic requirements (Nauta et al., $2006 b$ ). In general, organic farmers demand more robust cows (Ahlman et al., 2011), where robustness is understood as the ability to function well in the constraining organic environment (Strandberg and Roxström, 2000). The preferences of organic farmers differ from those of conventional farmers, with breeding objectives focused on disease resistance and longevity at the expense of milk production (Ahlman et al., 2014).
A new approach to defining the most suitable type of cow for organic farms is clearly needed. In this review paper, we consider (i) the current situation of breed diversity in dairy farming, (ii) the reasons why modern dairy cows are not adapted to pasture-based and organic systems, (iii) which traits should be improved to produce cows suited to organic systems, (iv) the performance of different dairy breeds (pros/cons) in organic and pastured-based systems worldwide, and finally (v) the direction in which selection of breeds for organic production should be aimed.

\section{Current breed diversity in dairy farming}

With a few exceptions (see below), worldwide dairy production is dominated by the American Holstein-Friesian breed (Oltenacu and Broom, 2010) (Fig. 1). The breed was developed in the US from animals imported from Northern Europe in the late 1800s, but was largely limited to North America until the early 1970s when large-scale exports began (Oltenacu and Broom, 2010). The extraordinary productive potential of American Holstein-Friesian cows when fed high quality diets led to the rapid development of highly specialised and technologically intensive conventional farms, able to offer equilibrated feed in a controlled and comfortable environment. In this favourable scenario, American Holstein-Friesian genes were quickly incorporated into the European dairy herd, thereby largely replacing the original Friesian breed as well as other local breeds (Brotherstone and Goddard, 2005). The expansion of this dairy farm model, 


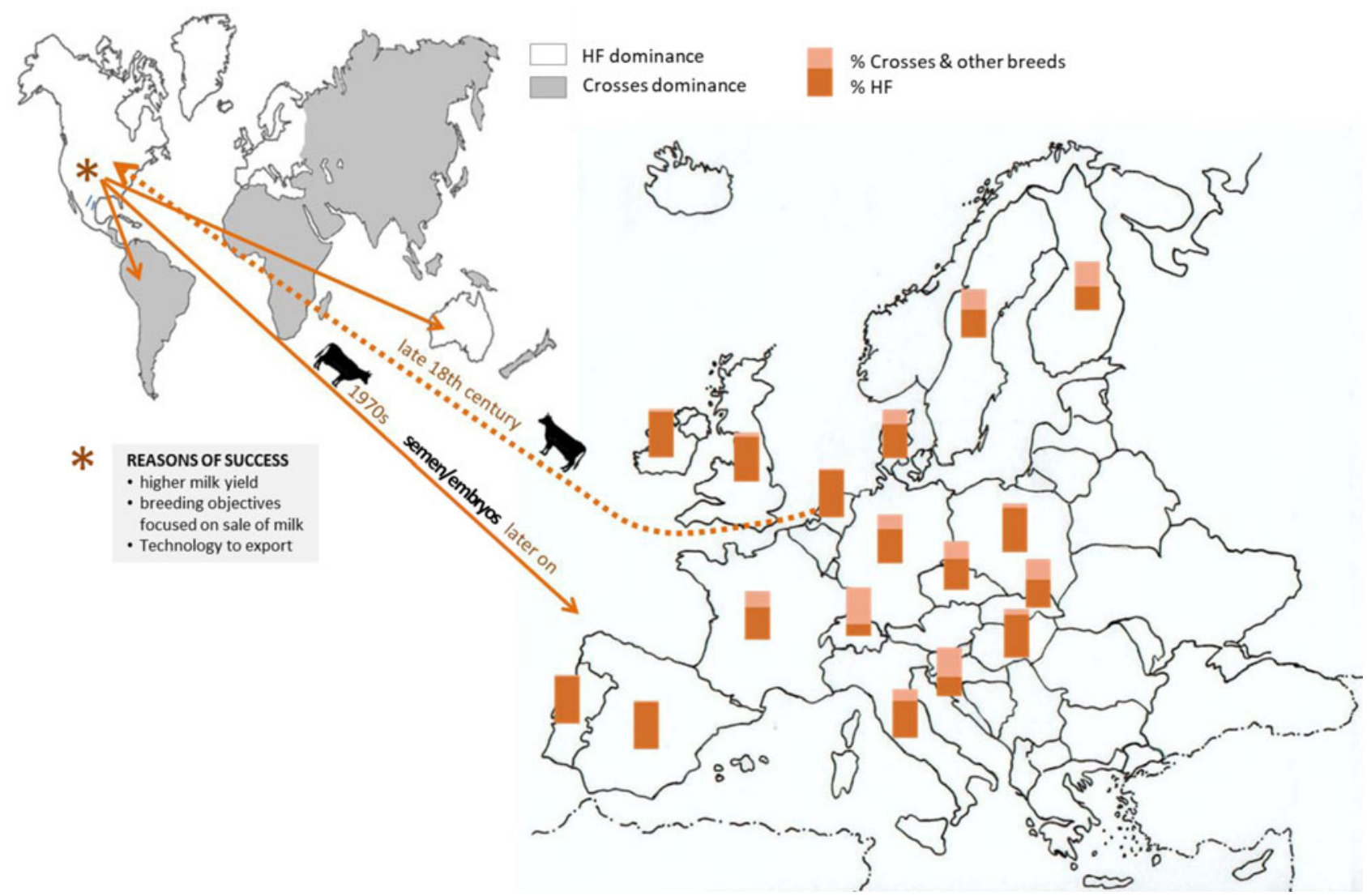

Fig. 1. Map showing the evolution and current situation of Holstein Friesian worldwide. Data source http://www.whff.info/documentation/statistics.php.

i.e. American Holstein-Friesian cows under intensive farming, lead to a large increase in milk production.

Although nutrition and management have helped to improve American Holstein-Friesian milk production, the dramatic increase in yield per cow was mainly due to the rapid progress in genetics (Brotherstone and Goddard, 2005; Oltenacu and Broom, 2010). It has been estimated that genetic selection accounts for more than $55 \%$ of the phenotypic gains in yield traits (Pryce and Veerkamp, 2001). This type of breeding has arisen as a result of high selection intensity and narrow breeding objectives aimed at increasing productivity, and the potential to increase efficiency by including traits that reduce input costs has been overlooked for decades. Such traits are often referred to as functional traits (i.e. animal health, udder health, longevity and reproductive traits) and have been shown to be negatively correlated with milk production (Ahlman, 2010) (Fig. 2).

Exceptions to the intensive American Holstein-Friesian productive model include pasture-based systems and systems focused on other rustic breeds such as pasture-adapted Holstein-Friesian, crosses or local breeds. The New Zealand system is, without doubt, the most important pasture-based system exported worldwide. It is a low input system comparable to the organic dairy sector from a nutritional point of view (Basset-Mens et al., 2009). Numerous examples of native breeds are found worldwide in smaller and local scale conventional milk production systems. Within Europe, Fleckvieh and Brown Swiss are the most common dairy breeds used in Austria and Switzerland (Haas and Bapst, 2004). In Nordic countries such as Sweden, Swedish Reds occur in higher proportions (45.8\%) than is usual worldwide, with other European breeds and crosses representing $6.4 \%$ of all cattle breeds (Ahlman, 2010).
Breed diversity in organic farming is similar to that described above for the conventional sector. American Holstein-Friesian cattle also dominate in organic dairy herds and show a similar increasing trend to that observed in conventional farming systems, e.g. in Germany (Nauta et al., 2006a), Canada (Rozzi et al., 2007) and Spain (Rodríguez-Bermúdez et al., 2016), although some countries depart from this tendency and maintain other local breeds.

In the Netherlands, organic farms specialising in milk production use purebred Holstein-Friesian cows (29\%) and crosses with more robust breeds (51\%), such as Brown Swiss, Montbeliarde and the dual breed Maas-Rijn-Ijssel. On multifunctional farms, the Holstein-Friesian breed represents a small fraction (2\%) of all breeds used, with cross-bred (57\%) and native Dutch breeds (34\%) (such as Maas-Rijn-Ijssel, Groninger White Face and Dutch Friesians) predominating (Nauta et al., 2009). On Swedish organic farms, most cows are the Swedish Red breed (54.3\%), and the proportion of Holstein-Friesian cows (35.5\%) is lower than in conventional herds (46.9\%), in favour of rarer breeds such as Jersey (1.5\%), the Swedish Polled breed (1.2\%) and various crosses (7.7\%) (Ahlman, 2010). In Austria and Switzerland, local breeds (Brown Swiss and Fleckvieh) are used in conventional systems. This also occurs in organic production systems in Switzerland, with Brown Swiss (51.7\%) and Fleckvieh (34.6\%) predominating (Haas and Bapst, 2004).

\section{Why are dairy cow breeds not adapted to pasture-based organic systems?}

As mentioned above, European and North American dairy herds have been selected for high milk production under intensive 


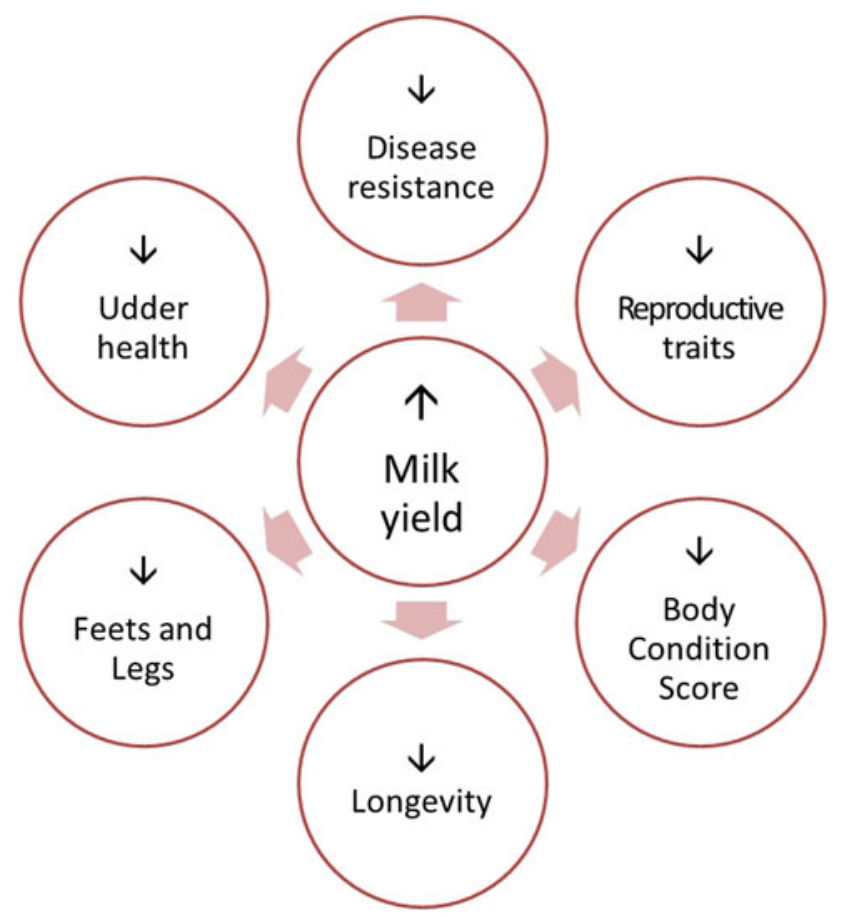

Fig. 2. Diagram showing the correlations between milk yield and functional and health traits in dairy cows.

farming conditions. Even under optimal management conditions, selection aimed at increasing milk yield has led to a decrease in health and reproductive efficiency in dairy cattle worldwide, as these traits are negatively correlated (Pryce and Veerkamp, 2001; Evans et al., 2002; Brotherstone and Goddard, 2005; Oltenacu and Broom, 2010). The reproductive performance of highly productive American Holstein-Friesian cows is greatly decreased when the cows are maintained in other environments. This has led to doubts as to whether these high input genotypes are suitable for forage-based organic farming systems (Nauta et al., 2006b; Horn et al., 2012), which are low input systems that require high fertility and reproductive performance rather than individual milk yield (Dillon et al., 2003b). High-yielding cows partition a high proportion of energy towards milk yield (Dillon et al., 2003a), but they are not able to achieve this without high-quality supplements. When these cows are fed only pasture their daily feed intake may decrease by $20 \%$ (Kolver, 2003) and they cannot, therefore, express their genetic potential and are at risk of suffering metabolic disorders in early lactation. As a result, it will be difficult for such cows to adapt to low input, organic systems. Moreover, in pasture-based dairy systems, high milk yielding cows display lower fertility, lower body condition and are culled at a higher rate than cows of average genetic merit (Rozzi et al., 2007). In pasture-based systems, such as used in New Zealand, Holstein-Friesian cows with a high potential for milk production also display lower survival rates, poor fertility and body condition, so that their profitability is greatly reduced at the end of their lifetime (Harris and Kolver, 2001).

To address the loss of performance of Holstein-Friesian in some farming systems, the genotype $\times$ environment $(\mathrm{G} \times \mathrm{E})$ interaction has been considered. $\mathrm{G} \times \mathrm{E}$ interaction can be defined as a change in the response of genotypes to different environments or to changes in the relative merit of genotypes in the different environments. $\mathrm{G} \times \mathrm{E}$ interactions are especially important when animals are reared under specific environmental conditions (such as organic production) for their potential to maintain genetic diversity. When animals are genetically adapted to specific conditions, they will be more productive and production costs will be lower (Charlesworth and Hughes, 2000).

$\mathrm{G} \times \mathrm{E}$ interactions for milk production are well described for conventional herds. Dairy producers in several countries have expressed concern regarding the declining fertility of cows with high proportions of Holstein-Friesian genes (Kearney et al., 2004). Some studies indicate that the already high negative genetic correlations between production, fertility and health in modern dairy cows reared in intensive production environments will increase further when cows are held in less intensive production environments (Harris and Kolver, 2001). However, we do not completely agree with this point of view, as organic systems must find a type of cow that is well adapted to organic systems (characterised by lower productive pressure), thus allowing the breed to perform better in terms of reproduction and resistance to local infections.

Within the organic sector, $\mathrm{G} \times \mathrm{E}$ interactions have been observed in Holstein-Friesian cows bred for production traits in the Netherlands (Nauta et al., 2006b) and for fertility traits in Sweden (Ahlman, 2010). Due to GXE interactions, bulls selected for use in conventional systems may not be suitable for organic systems (Nauta et al., 2006b). If a trait such as milk yield is controlled by different sets of genes in different environments, it is possible that sire rankings will differ between systems (Pryce et al., 1999; Ahlman, 2010). Identification of $\mathrm{G} \times \mathrm{E}$ interactions is therefore one of the main challenges facing organic dairy systems, in order to prevent livestock performance from being constrained by the environment. Identification of $\mathrm{G} \times \mathrm{E}$ interactions should be considered positively to enable organically reared cows to express their productive performance in an environment where animal welfare is given particular importance under low productive pressure.

\section{Which traits should be improved?}

The search for the ideal dairy cow is not only of concern in organic farming systems. Producers worldwide have recognised that profitability does not necessarily depend on high milk production, especially as the cost of maintaining a dairy herd continues to rise (Bluhm, 2009). Farmers who run low input systems generally prefer more robust animals that maintain high yields but suffer few health problems (Nauta, 2001). Studies in New Zealand (Harris and Winkleman, 2000) and Ireland (Dillon et al., 2003a, 2003b), where dairy production is based on pasture, have indicated that the most profitable cows for these environments are different from those selected under a high-concentrate regime.

Milk production is not the only trait that must be considered. Although information is scarce, organic farmers questioned about which traits they would prioritise emphasised longevity, roughage intake and disease resistance, especially resistance to mastitis and parasites, even at the expense of milk production (Ahlman et al., 2014). Furthermore, fertility, strong feet and legs, high milk fat and protein yield, low somatic cell count (SCC), feed intake and feed conversion are also important parameters (Haas and Bapst, 2004; Rodríguez-Bermúdez et al., 2016).

In cattle production, longevity has been considered to reflect the capacity of a cow to avoid being culled due to low production, low fertility or illness (Vollema and Groen, 1996). While cattle 
can potentially live for 20 years or longer, few dairy cattle live longer than 6 years on most modern dairy farms (Rushen and Passillé, 2013). The decline in longevity in dairy farming generally results from involuntary culling. This clearly reduces the profitability of dairy farms and does not satisfy the aims of sustainable dairy production (Ahlman et al., 2011; Rushen and Passillé, 2013). Dairy cow longevity, also understood as durability with acceptable production, is especially important in organic production (Ahlman et al., 2011; Slagboom et al., 2016). As with the other aspects considered here, studies evaluating longevity and the causes of culling in organic systems are scarce. In a survey carried out in Ontario (Canada), infertility was found to be the principal reason for culling in organic systems, followed by mastitis and foot problems, even though owners of less productive farms also mentioned low productivity (Rozzi et al., 2007). Farmers from both the most and least productive organic farms reported that the age of the animal was a more important reason for culling than type of cow, injury or temperament. Within Europe, similar findings were obtained in a study carried out in Sweden (Ahlman, 2010; Ahlman et al., 2011), with the main reasons for culling in organic herds being poor udder health, followed by low fertility, low production and foot problems. By contrast, a recent study in organic dairy farms in Northern Spain (Rodríguez-Bermúdez et al., 2016) found that the age of animal was the main reason for culling (73.2\%), distantly followed by infertility (14.3\%), mastitis $(10.7 \%)$ and laminitis $(1.8 \%)$. These findings were attributed to farmers not being able to afford to cull animals with subclinical pathologies, as indicated by a higher culling rate than replacement rate. This has led to farmers being dissatisfied with the cows available for organic production systems.

Organic farmers may have other priorities in addition to longevity when choosing the most suitable cows for their farms. While some organic farmers continued to specialise, many others have transformed their farms into multifunctional businesses producing cheese and yogurt, providing farm gate shops (selling milk and meat products) and promoting or involving nature development and conservation, crop production, care farming, ecotourism and/or recreation (Nauta et al., 2009). Such differences in farming strategies may imply different demands regarding breed characteristics (Van Diepen et al., 2007). On multifunctional farms, for example, characteristics other than milk production may be important. Jersey cow milk contains more fat and protein than Holstein-Friesian milk, leading to higher yields of cheese per unit of standardised milk, with faster formation rates (Auldist et al., 2004). Other characteristic that farmers in multifunctional systems value is the capacity of a breed to produce meat of sufficient quality to be sold as a co-product (Van Diepen et al., 2007; Nauta et al., 2009), as with dual purpose breeds such as Meuse Rhine Yssel, Normande, Fleckvieh, Milking Shorthorn, Brown Swiss and Montbeliarde. This is a good way of obtaining profit from male calves born on the farms (Van Diepen et al., 2007), as well as from heifers/cows that must be culled (for reasons other than disease). Using local and rare breeds can also serve as a marketing tool and can help attract farm visitors (Van der Ploeg, 2003). Moreover, consumers may equate their favourite product with a specific (local) breed. Indeed, taking consumers' opinions about breed protection into account may be useful, as consumers may associate some breeds with what they expect to find on organic farms (local or traditional breeds) and may be willing to pay a premium for this. In fact, $41 \%$ of cattle reared on multifunctional farms in Netherlands are local breeds, because these can be presented to society and consumers as having a clear and distinct organic identity (Nauta et al., 2009).

\section{Performance of different breeds in organic and pastured-based systems worldwide: the pros and cons}

The identification of breeds that are best suited to organic production is a subject of much debate (Nauta et al., 2009). According to Van Diepen et al. (2007), breeds or strains of animals should be selected to avoid specific diseases or health problems associated with intensive production. The main concerns are related to the ability of highly productive breeds to adapt to organic environments, characterised by lower energy and protein intake and limited use of antibiotics. Sustainable organic animal production should also be adjusted to local conditions, and different types of animals may be required for different production situations (Rozzi et al., 2007).

It is almost impossible at present to find animals that have been bred specifically for organic production systems, and it has therefore been suggested that there is a vicious circle regarding animal breeding. Farmers do not know what type of animal they need and take refuge in 'tried and trusted' conventional breeds. Organic dairy farmers express similar preferences to those expressed by conventional farmers regarding breeding goals and the various aspects of production, conformation and functionality of animals (Slagboom et al., 2016). By contrast, their actual choices and expressed preferences regarding breeds or cross-breeds are quite varied, unlike conventional farmers who generally agree that Holstein-Friesian cows are the best. This difference can be explained by the fact that organic dairy farming is a young, developing sector and the search for suitable breeds of cattle is at an early stage. There is also a lack of good information about the qualities and performance of breeds and cross-breeds for organic production. In this context, many organic farmers are experimenting with both pure HolsteinFriesian cows inherited from the conventional sector and crosses between these and other breeds, although very little information is available about the resulting cross-breeds. The use of rustic Holstein-Friesian cows is even less well explored. Table 2 presents a summary of pros and cons for different breeds or types of cattle.

\section{Pros and cons of pure-bred cattle other than Holstein-Friesian}

It is widely accepted that local breeds are more robust and genetically better adapted to their environment than Holstein-Friesian cows (Van Diepen et al., 2007). Local breeds have been suggested to suit organic production and to be important for retaining genetic diversity (Ahlman, 2010). They adapt well to organic systems because they utilise lower quality feed, are more resilient to climatic stress and are more resistant to local parasites and diseases than Holstein-Friesian cows. Use of local breeds also preserves the genetic variance of species. Such breeds can be saved for future generations of farmers by reintroducing them into organic farming systems (Nauta, 2001). Moreover, the rearing of autochthonous breeds could be subsidised by the EU or regional governments to conserve genetic traits or cultural heritage (Commission Regulation (EU) No 702/2014 2014) and could be utilised as a marketing tool.

Few studies have been carried out to evaluate the performance of other pure breeds relative to Holstein-Friesian in organic dairy farming systems. As far we are aware, the most complete survey to 
Table 2. Pros and cons of the use of Holstein Friesian, other pure-bred and cross-bred cows in organic dairy systems

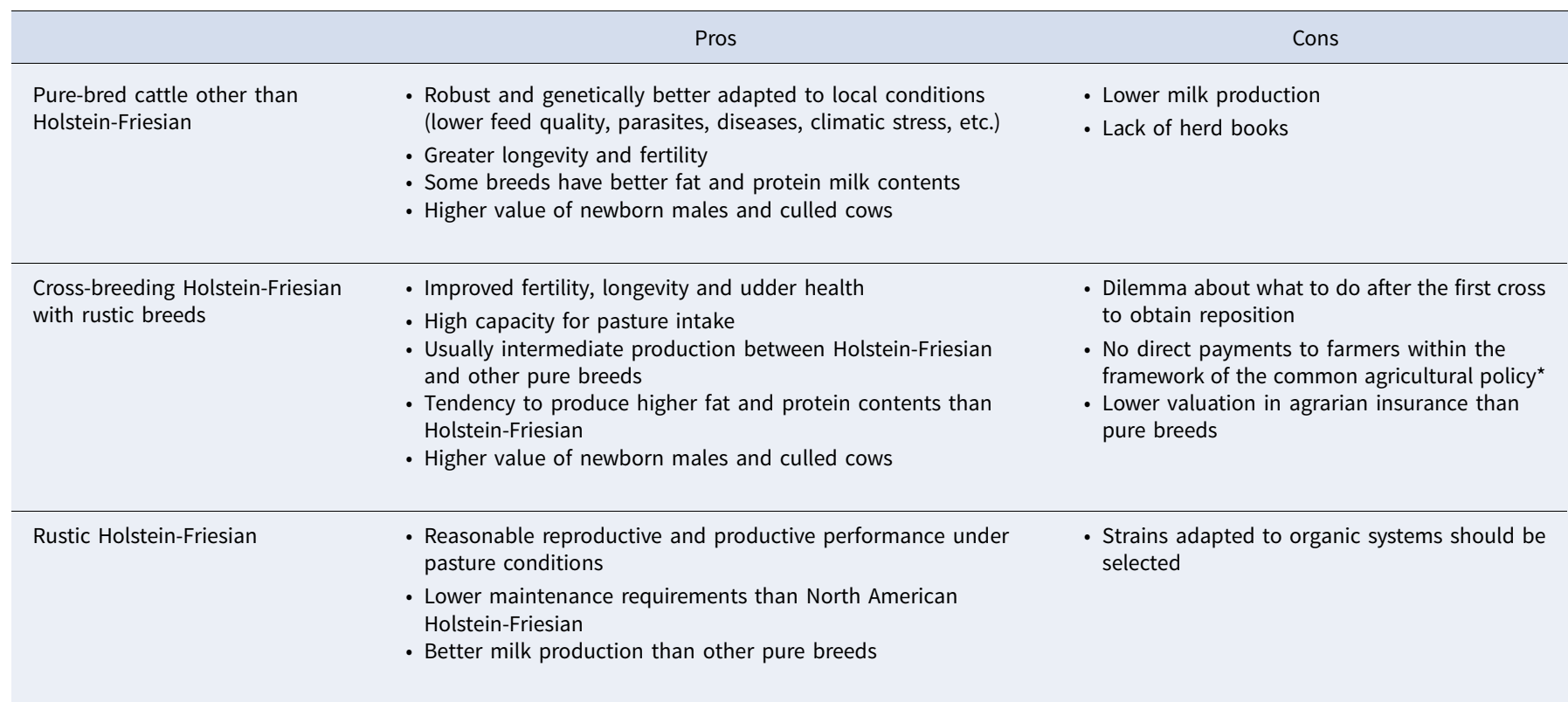

${ }^{\star}$ REGULATION (EU) No 1307/2013 OF THE EUROPEAN PARLIAMENT AND OF THE COUNCIL of 17 December 2013 establishing rules for direct payments to farmers under support schemes within the framework of the common agricultural policy.

date was conducted in the Netherlands with eight different breeds: Holstein-Friesian, Dutch Friesian, Brown Swiss, Montbeliarde, Jersey (considered as milk-aptitude breeds) and the dual-aptitude breeds Groningen White Headed, Meuse Rhine Yssel and Fleckvieh (de Haas et al., 2013) Under the study conditions, Holstein-Friesian produced the highest milk yields, followed by Brown Swiss and Montbeliarde (90 and 82\% of the HolsteinFriesian's milk production respectively), whereas Jersey cows produced the lowest yields (61\%). However, the protein and fat contents of Jersey cow milk were much higher than those of Holstein-Friesian milk (only Fleckvieh obtained lower scores). Furthermore, SCC (an indicator of milk quality) was higher (worse) in Jersey cow milk than in milk from all other breeds, as found in other studies carried out in conventional systems (Berry et al., 2007) and possibly explained by a dilution effect as milk yield increases (Villar and López-Alonso, 2015). Evaluation of reproductive performance showed that Fleckvieh and Groningen White Headed cows obtained the highest scores for fertility, whereas Holstein-Friesian and Brown Swiss cows obtained the lowest scores.

Similar results were obtained in a study carried out in Switzerland (Roesch et al., 2005) to evaluate the performance of organic dairy cows (involving 60 farms with a breed diversity of 55.1\% Holstein-Friesian $\times$ Fleckvieh, $\quad 19.7 \%$ Holstein-Friesian, 18.8\% Fleckvieh and 6.4\% Brown Swiss, Jersey and Montbeliarde). Breed had a strong impact on milk yield: Fleckvieh cows produced low volumes of milk, whereas pure-bred Holstein cattle and cows of other breeds (Montbeliard, Brown Swiss, and even Jersey) produced relatively high volumes of milk.

A study carried out in Austria compared only Brown Swiss and Holstein-Friesian cows (Horn et al., 2012); the Holstein-Friesian cows included in the study were selected for their reproductive performance, and Brown Swiss were reared in conventional systems. Interestingly, the Brown Swiss cows produced more milk with higher fat and protein contents, but showed poorer reproductive efficiency (measured as inter-parturition intervals) than the Holstein-Friesian cows. The authors concluded that Holstein-Friesian cows can be selected for use in pasture-based systems, although at the expense of milk production (Pryce et al., 1999). The results of this study may seem contradictory, but they simply confirm the fact that both the breed and the type of selection are important. Independently of the breeds used in organic dairy farming, the particular cows selected must be adapted to specific environmental and management conditions.

Finally, a recent study carried out by our research group (Rodríguez-Bermúdez et al., 2017) to evaluate the performance of diverse breeds (Holstein-Friesian, Swedish Red, Brown Swiss and crosses of Holstein-Friesian) on organic dairy farms in North Spain showed that Holstein-Friesian cows tend to produce more milk, but with significantly lower fat and protein contents, than the other breeds. No differences were observed in SCC in any case.

As studies of organic farming systems are scarce, one way of obtaining information about the performance of other breeds in organic systems is to observe how they perform in conventional pasture-based systems. Within Europe, some relevant studies have been conducted in Ireland. One study compared the performance of Normande and Montbeliarde cattle with that of Dutch and Irish strains of Holstein-Friesian in pasture-based systems (Dillon et al., 2003a, 2003b). Dutch Holstein-Friesian cows produce more milk than the other breeds, and Normande cows produced milk with higher fat and protein contents than that produced by Montbeliarde and Dutch and Irish Holstein-Friesians (Dillon et al., 2003a). Normande and Montbeliarde displayed better reproductive performance than both strains of HolsteinFriesian (Dillon et al., 2003b), probably due to the negative effect of genetic selection for milk yield on reproductive performance (Evans et al., 2002). Finally, up to 6-8 years, the survival rates of Montbeliarde (49.2\%) and Normande cows (55.8\%) were 
higher than those of Irish Holstein-Friesian (20.6\%) and Dutch Holstein-Friesian (39.7\%) (Dillon et al., 2003b). In other studies in Ireland, Holstein-Friesian cows were found to produce significantly more milk than Jersey cows (Prendiville et al., 2011), although there were no differences in SCC or udder health. As expected, Jersey cow milk contained significantly higher amounts of protein and fat (Prendiville et al., 2011) and the body condition score (BCS) and dry matter intake (DMI) were higher in Jersey cows than in the other breeds considered (Prendiville et al., 2009).

Overall, the available information for both organic and pastured-based conventional systems indicates that rustic breeds are better adapted to local conditions, displaying greater longevity and better reproductive performance than Holstein-Friesian cows. By contrast, local breeds always produce less milk than Holstein-Friesians, although the fat and protein contents of the milk are generally higher. Local breeds would therefore be acceptable in countries where the payment system is based on solids or where consumers are willing to pay for different types of products or for breed protection. Moreover, Jersey milk coagulates more quickly and forms a firmer curd than Holstein-Friesian milk, characteristics that may be of interest for farmers wishing to produce cheese (Auldist et al., 2004). Finally, the possible lack of herd books and selection programs for breeds other than HolsteinFriesian may hamper the selection procedure.

\section{Pros and cons of cross-breeding Holstein-Friesian with rustic breeds}

Until relatively recently, cross-breeding was considered to offer little advantage to conventional dairy producers, probably due to the lower milk production potential of most breeds relative to the Holstein-Friesian (Prendiville et al., 2011). However, a decrease in additive genetic merit for functional traits, particularly fertility and health (which are important for longevity) has resulted in renewed interest in cross-breeding conventional dairy cattle in the past decade (Lopez-Villalobos et al., 2000), and some conventional dairy producers now include crossbreeding in their breeding programs. Cross-breeding highly productive Holstein-Friesian and local breeds is perceived as a good option for organic farmers, and many more organic farmers than conventional farmers cross-breed cattle. In a survey carried out in Ontario, Rozzi et al. (2007) found that about $40 \%$ of organic farmers questioned had cross-bred some or all of their cows, compared to conventional producers questioned. The breeds used for cross-breeding in organic farming are different from those used in conventional systems. While Jersey and Brown Swiss are the breeds most commonly chosen by conventional producers for crossing with Holstein-Friesian, organic producers have also experimented with other breeds, such as Dutch Belted, Milking Shorthorn and Fleckvieh; crosses with Dutch Belted are common and designed to increase the breed rusticity and production capacity when cows are only given forage.

Information about cross-breed performance on organic farms is scarce. Cross-breeds between Holstein-Friesian cows and other European breeds generally produce milk yields that are intermediate between those of both pure breeds (de Haas et al., 2013). Some studies show that cross-breeds produce milk with higher protein and fat contents than milk produced by Holstein-Friesian cows (Rodríguez-Bermúdez et al., 2017); however, de Haas et al., (2013) observed that crosses again performed better than both parental breeds (heterosis). No differences were found regarding SCC, which is more closely related to the management system than to breed type (Orjales et al., 2016; Rodríguez-Bermúdez et al., 2017). In Germany, Swalve (2007) found that in comparison with purebred Holstein-Friesian cows, Holstein-Friesian $\times$ Swedish Red crosses yielded advantages in terms of milk production, fat and protein contents of milk (all higher) and SCC (lower). Finally, de Haas et al. (2013) observed that crosses between Holstein-Friesian cows and other breeds such as Dutch Friesian, Brown Swiss, Groningen White Headed, Jersey, Meuse Rhine Yssel, Montbeliarde and Fleckvieh improved fertility and sometimes udder health (except Jersey and Groningen White Headed). Similar results were found by Swalve (2007) for crosses between Holstein-Friesian and Swedish Red or Brown Swiss cows. Most of these studies can be considered preliminary, as they involved very few farms where breed diversity exits. As the organic dairy sector is currently growing, new studies involving a more farms and with well-planned experimental designs must be conducted to measure the performance of cross-breeding herds under organic productive systems.

Considering the available information on cross-breeding in conventional pasture-based systems, the New Zealand Jersey $\times$ Holstein-Friesian experience is important (Buckley et al., 2014). Many studies have been conducted in recent years, both within and outside of New Zealand, based on evidence of the average superiority of cross-bred cows compared with any of the parental lines (Holstein-Friesian, Ayrshire and Jersey). This is due to the high potential for increased profits to be gained from cross-breeds (Lopez-Villalobos et al., 2000) because of their high capacity for pasture intake (Prendiville et al., 2009) and efficiency of conversion of feed to milk (Garrick, 2002), as well as improved fertility (Auldist et al., 2007) and longevity (Harris et al., 1996). Jersey cows, known to produce milk with high butterfat content, could be used in cross-breeding programs with Holstein-Friesian cows to improve butterfat percentage in a single cross (Bluhm, 2009). In terms of reproduction, Holstein-Friesian $\times$ Jersey crosses performed better than pure Holstein-Friesian, with higher conception and pregnancy rates (Auldist et al., 2007). Studies carried out in pasture-based systems in Ireland obtained similar results to those obtained in New Zealand (Prendiville et al., 2009, 2011), i.e. Holstein-Friesian (dam) $\times$ Jersey (sire) cross-breeds produced intermediate milk yield and fat and protein contents than both pure-bred parents, with Holstein-Friesian performing better for milk production and Jersey for fat and protein contents. No differences were found in relation to SCC and mastitis.

Once farmers know which breeds they wish to cross, the next dilemma is to decide what to do after the first cross. One possible strategy would be to produce first crosses, which would involve maintaining some pure-bred cows and mating the best performers while mating the other pure-bred cows with the desired sire to produce replacements for the cross-bred proportion of the herd. Other options include using continuous rotational cross-breeding strategies or even producing composite breeds. A two-breed rotational cross maintains $67 \%$ of the direct heterosis, while three- and four- breed crosses maintain respectively $86 \%$ and $94 \%$ of the direct heterosis. The challenge is to find several breeds of suitable merit to produce a cross-bred population that is better (economically) than the pure-bred population (Pryce and Veerkamp, 2001).

Backcrossing animals does not always produce good results. For example, backcrossing Holstein-Friesian $\times$ Brown Swiss crosses with a Brown Swiss resulted in lower milk yields in one study (Dechow et al., 2007). In another, expected heterosis was close to zero in second and third breed cross-breeding systems due to unfavourable recombination effects on yield (Pedersen and Christensen, 1989). A recent study conducted in Argentina 
found that once first crosses (Holstein-Friesian $\times$ Jersey, HolsteinFriesian $\times$ Guernsey, Holstein-Friesian $\times$ Brown Swiss) have been carried out, Holstein-Friesian traits of interest can be recovered by breeding cross-bred dams with a Holstein-Friesian bull (Mancuso, 2017).

In conclusion, cross-breeding highly productive HolsteinFriesian and local breeds may be a viable option for organic producers. Although this approach seems well-established for breeds such as Jersey, further investigation with other breeds is required before it is applied on a large scale (Ahlman, 2010). The decision to produce cross-breeds is usually based on a desire to improve functional traits by taking advantage of heterosis. However, the effects of heterosis can be positive or negative, and the overall effects are difficult to predict (Bluhm, 2009). In addition, the choice of breeds is critical because, as already pointed out, herd books or selection programs may not have been established for minor breeds, as some farmers carry out progeny testing on their own herds.

\section{Pros and cons of rustic Holstein-Friesian}

It seems that Holstein-Friesian cows maintain genes from their ancestors and still show reasonable reproductive and productive performance under pasture conditions. In fact, a study in the UK has shown that when suitable strains are chosen, Holstein-Friesians are the most profitable breed for use in both conventional and organic systems (Brotherstone and Goddard, 2005). It has also been demonstrated that, under experimental conditions based on grazed pastures and moderate concentrate supplementation, maximum economic profit was obtained with Holstein-Friesian cows with a low percentage of North American genes (Baudracco et al., 2010). This may explain why some farmers do not use local breeds and prefer to continue using Holstein-Friesian cows (Nauta, 2001). The best example of Holstein-Friesian cattle adapted to pasture-based systems is without any doubt the New-Zealand Holstein-Friesian. These cattle were initially selected for fat yield, then for fat and protein and against milk volume, and more recently for economic efficiency, including maintenance costs (Harris, 1998). The New Zealand dairy system is pasture-based with low supplementation; most of the cows calve in spring and $90 \%$ of the milk is made into dairy products. Farmers are paid for the amount of protein and fat produced and a deduction is made for milk volume produced (Harris and Kolver, 2001). In general, this strain of New Zealand Holstein-Friesian produces milk with higher fat and protein contents and it displays better fertility, BCS, survival and overall economic performance than the North American Holstein-Friesian (Harris and Kolver, 2001). Moreover, New Zealand HolsteinFriesian cows have lower maintenance requirements and DMI in early lactation than the North American Holstein-Friesian (Patton et al., 2008). It has been concluded that New Zealand Holstein-Friesian cows selected under pastoral feeding are better adapted to pasture-based systems than North American Holstein-Friesian cows (Macdonald et al., 2005). However, New Zealand Holstein-Friesian adapted to pasture-based systems may not be the best alternative for use in European organic farms, as they are selected to produce high quantities of milk solids, and the milk payment system in Europe mainly considers volume. European organic farmers must have their own rustic Holstein-Friesian with good reproduction and disease resistance but that maintains good milk yield production.

Some examples of European Holstein-Friesian cows, i.e. Dutch and Irish strains, maintain some rustic traits. In the case of Dutch
Friesian, a breeding system called family breeding was developed by a group of individual breeders of the remaining Dutch-Friesian cows in the Netherlands. This group of farmers represented only $8 \%$ of organic farms in Netherlands in 2001 (Nauta, 2001; Nauta et al., 2009). The purpose of this breeding system was to maintain the original Dutch Friesian breed (Fries-Hollands) (Endendijk and Baars, 2001). Farmers select and breed their own replacement animals, both female and male, thus producing animals that are highly adapted to the local environment (Nauta, 2001). However, the Dutch-Friesian family breeding system depends on farmers' breeding skills, and professional support may be required for the continued success of the system. Although the inbreeding rate was $4.5 \%$ in 2005 (which is acceptable with the rate of more than $6 \%$ in Holstein-Friesian cattle), after many years of family breeding the animals become increasingly more closely related, and organic farmers therefore do not regard the system as a good option. Conventional Irish systems have also selected a particular Holstein-Friesian strain, which has been demonstrated to survive better on pasture $(39.7 \%$ lasted for $6-8$ years) and shows better reproductive performance than the American Holstein-Friesian (21\% lasted for 6-8 years) (Dillon et al., 2003b).

\section{Which direction should selection of breeds for organic sector take in coming years?}

This analysis of how different breeds and crosses perform in organic dairy systems worldwide clearly shows that there are advantages and disadvantages associated with all, the importance of the various pros and cons varying depending on the individual conditions on a particular farm. It is also clear that opting to use different breeds is risky and will remain costly, as a medium/longterm process, until homogenous herds are established.

As most organic dairy farms have been reconverted from more or less intensive conventional farms, where the predominant breed is the American Holstein:Friesian, the recommended option for most organic farms seems to be to continue using this breed while identifying those cows best adapted to the particular conditions of these productive systems, although bearing in mind that trying out different breeds may also be worthwhile under certain circumstances.

Once it has been decided which breed or crosses best fit the particular interests of organic farmers, the next, but not less important, decision to make involves selection of which particular individuals to use, either pure-bred or cross-bred. Therefore, the challenge in the coming years in organic dairy breeding is to provide an organic genetic merit index that satisfies the famers' needs. Some efforts have been made to elaborate total merit indexes for organic dairy production, in Switzerland, Austria, Germany and Canada (Haas and Bapst, 2004; Rozzi et al., 2007). These indexes were thought to enable farmers to identify the conventional sires best adapted to organic production. Unfortunately, these first efforts were rather unsuccessful because of inadequate support (Ahlman, 2010). Although the organic sector is increasing, it remains a minority, and the market volume of this productive sector may not be profitable for maintaining bulls only for organic farms. A potentially good alternative would be to develop breeding indexes adapted to pasture-based systems, which would not only be suitable for organic systems but also for conventional systems with high grazing intensity. An adequate body of knowledge and practical applicability already exists in countries such as Ireland and New Zealand, where the solids 
(kilograms of fat and protein) and high fertility indexes are maximised, and milk yield production, live weight and somatic cell counts are minimised (in terms of genetic value). Moreover, recent technological developments have led to the identification of cows that are more resistance to diseases (based on genomic tests) which may be useful for selecting the least susceptible individuals in the herd for breeding, in the first step to increase the herd 'robustness'.

All the above-mentioned tools have been developed for conventional dairy systems, so that breeding values must be converted to organic systems based on information obtained under organic conditions. Only then will organic farmers be able to select best breeding bulls and cows for organic production (Nauta et al., 2006b). If breeding values are converted or estimated, bulls will have to be re-ranked as the classification will be different, as a result of $\mathrm{G} \times \mathrm{E}$ interactions (Nauta et al., 2006b; Ahlman, 2010). In our opinion, selection indexes for organic production should place more emphasis on functional traits (especially fertility and longevity) than on production traits, as well as on the capacity of the animals to perform well in pasture-based systems (i.e. considering robustness of feet and legs and grazing capacity). For farmers transforming milk into dairy products, special emphasis should be placed on solids production and the transformation capacity.

\section{Conclusions}

Unlike the conventional farming sector, organic dairy farming on both local and large scales is very heterogeneous, and no single type of cow will be suitable for all scenarios. Because of the legislation associated with organic farming (mainly involving nutrition and allopathic treatments) and the high dependence on the environment, organic farmers generally demand robust cows that are sufficiently productive to yield profits. Analysis of the available data indicates that (i) there is no single alternative breed (rustic Holstein-Friesian, other rustic breeds or crosses) as there are advantages and disadvantages associated with all, and (ii) the strong genotype $\times$ environmental interactions demand different strategies to deal with very diverse situations. For example, farms producing milk for payment systems that recompense volume would obtain benefits from high milk yielding cows, i.e. rustic Holstein-Friesian may be the best option. Although most Holstein-Friesian cows are currently selected for use in conventional systems, this situation could be reversed by the implementation of an organic merit index that takes into account organic breeding goals. On the other hand, farms producing milk either for systems that recompense milk solids or for transformation into dairy products would benefit from using pure-bred cows other than Holstein-Friesian or cross-breeds. Finally, organic farmers who focus on rural tourism, farm schools, or other businesses where marketing strategies must be taken into account, could benefit from using local breeds (when possible) or any other rustic breed valued by customers.

Acknowledgements. Ruth Rodríguez Bermúdez is in receipt of a predoctoral research contract (Ref.FPU14/01476) from the Spanish Ministry of Education, Culture and Sport.

\section{References}

Ahlman T (2010) Organic Dairy Production. Herd Characteristics and Genotype by Environment Interactions (Doctoral thesis). Swedish
University of Agricultural Sciences. Available at https://pub.epsilon.slu.se/ 2354/1/ahlman_t_100922.pdf.

Ahlman T, Berglund B, Rydhmer L and Strandberg E (2011) Culling reasons in organic and conventional dairy herds and genotype by environment interaction for longevity. Journal of Dairy Science 94, 1568-1575.

Ahlman T, Ljung M, Rydhmer L, Röcklinsberg H, Strandberg E and Wallenbeck A (2014) Differences in preferences for breeding traits between organic and conventional dairy producers in Sweden. Livestock Science 162, $5-14$.

Auldist MJ, Johnston KA, White NJ, Fitzsimons WP and Boland MJ (2004) A comparison of the composition, coagulation characteristics and cheesemaking capacity of milk from Friesian and Jersey dairy cows. Journal of Dairy Research 71, 51-57.

Auldist MJ, Pyman MFS, Grainger C and Macmillan KL (2007) Comparative reproductive performance and early lactation productivity of Jersey $x$ Holstein cows in predominantly Holstein herds in a pasture-based dairying system. Journal of Dairy Science 90, 4856-4862.

Basset-Mens C, Ledgard S and Boyes M (2009) Eco-efficiency of intensification scenarios for milk production in New Zealand. Ecological Economics 68, 1615-1625.

Baudracco J, Lopez-Villalobos N, Holmes CW and Macdonald KA (2010) Effects of stocking rate, supplementation, genotype and their interactions on grazing dairy systems: a review. New Zealand Journal of Agricultural Research 53, 109-133.

Berry DP, Lee JM, Macdonald KA, Stafford K, Matthews L and Roche JR (2007) Associations among body condition score, body weight, somatic cell count, and clinical mastitis in seasonally calving dairy cattle. Journal of Dairy Science 90, 637-648.

Bluhm W (2009) The role of crossbreeding in UK dairy breeding. Available at https:/www.yumpu.com/en/document/view/11739604/the-role-of-crossbreeding-in-uk-dairy-breeding.

Brotherstone S and Goddard M (2005) Artificial selection and maintenance of genetic variance in the global dairy cow population. Philosophical Transactions of the Royal Society of London. Series B, Biological Sciences 360, 1479-1488.

Buckley F, Lopez-Villalobos N and Heins BJ (2014) Crossbreeding: implications for dairy cow fertility and survival. Animal: An International Journal of Animal Bioscience 8, 122-133.

Charlesworth B and Hughes K (2000) The maintenance of genetic variation in life-history traits. In Singh R and Krimbas C (eds), Evolutionary Genetics. Cambridge: Cambridge University Press, pp. 369-392.

Commission Regulation (EC) (2008) Commisión Regulation (EC) No 889/ 2008 of 5 September 2008 laying detail rules for the implementation of Council Regulation (EC) No 834/2007 on organic production and labelling of organic products with regard to organic production, labelling and control. Official Journal of the European Union L250, 1-84.

Commission Regulation (EU) No 702/2014 (2014) Commission Regulation (EU) No 702/2014 of 25 June 2014 declaring certain categories of aid in the agricultural and forestry sectors and in rural areas compatible with the internal market in application of Articles 107 and 108 of the Treaty on the Function. Official Journal of the European Union 57 193/1-193/75.

Council Regulation (EC) (2007) Council Regulation (EC) No 834/2007 of 28 June 2007 on organic production and labelling of organic products and repealling Regulation (ECC) No 2092/91. Official Journal of the European Union L189, 1-23.

Dechow CD, Rogers GW, Cooper JB, Phelps MI and Mosholder AL (2007) Milk, fat, protein, somatic cell score, and days open among Holstein, Brown Swiss, and their crosses. Journal of Dairy Science 90, 3542-3549.

de Haas Y, Smolders EAA, Hoorneman JN, Nauta WJ and Veerkamp RF (2013) Suitability of cross-bred cows for organic farms based on crossbreeding effects on production and functional traits. Animal: An International Journal of Animal Bioscience 7, 655-664.

Dillon P, Buckley F, O'Connor P, Hegarty D and Rath M (2003a) A comparison of different dairy cow breeds on a seasonal grass-based system of milk production: 1.Milk production, live weight, body condition score and DM intake. Livestock Production Science 83, 21-33.

Dillon P, Snijders S, Buckley F, Harris B, O'Connor P and Mee JF (2003b) A comparison of different dairy cow breeds on a seasonal grass-based system 
of milk production: 2. Reproduction and survival. Livestock Production Science 83, 35-42.

Endendijk D and Baars T (2001) Family breeding at the Rivelinohoeve, a case study. In Hovi M and Baars T (eds), 4th NAHWOA Workshop. Network for Animal Health and Welfare in Organic Agriculture. Wageningen, The Netherlands: University of Reading (UK), pp. 35-43.

Evans RD, Buckley F, Dillon P and Veerkamp RF (2002) Genetic parameters for production and reproduction of spring-calving upgraded Holstein-Friesian cows in Irland. Irish Journal of Agricultural and Food Research 41, 43-54.

Garrick DJ (2002) Principles of genetic improvement in dairy herds. In Holmes CW, Brookes IM, Garrick DJ, Mackenzie DDS, Parkinson TJ and Wilson GF (eds), Milk Production From Pasture-Principles and Practices. Palmerston North, New Zealand: New Zealand Massey University, pp. 475-593.

Gouttenoire L, Cournut S and Ingrand S (2013) Participatory modelling with farmer groups to help them redesign their livestock farming systems. Agronomy for Sustainable Development 33, 413-424.

Haas E and Bapst B (2004) Swiss organic dairy farmer survey: Which path for the organic cow in the future? Organic livestock farming: potential and limitations of husbandry practice to secure animal health and welfare and food quality. $2^{\text {nd }}$ SAFO Workshop 35-41. Witzenhausen (Germany).

Harris BL (1998) Breeding dairy cattle for economic efficiency: A New Zealand pasture-based system. 6th World Congress Genetic Applied to Livestock Production 383-386. Armidale (Australia).

Harris BL and Kolver ES (2001) Review of holsteinization on intensive pastoral dairy farming in New Zealand. Journal of Dairy Science 84, 56-61.

Harris BL and Winkleman AM (2000) Influence of North American Holstein genetics on dairy cattle performance in New Zealand. In Proceedings of the New Zealand Large Herds Conference, pp.122-136. Christchurch (New Zealand).

Harris BL, Clark JM and Jackson RG (1996) Across breed evaluation of dairy cattle. New Zealand Society of Animal Production 56, 12-15.

Horn M, Steinwidder A, Podstatzky L, Gasteiner J and Zollitsch W (2012) Comparison of two different dairy cow types in an organic, low input milk production system under Alpine conditions. Agriculture and Forestry Research 362, 322-325.

Kearney JF, Wall E, Villanueva B and Coffey MP (2004) Inbreeding trends and application of optimized selection in the UK Holstein population. Journal of Dairy Science 87, 3503-3509.

Kolver ES (2003) Nutritional limitations to increased production on pasturebased systems. Proceedings of the Nutrition Society 62, 291-300.

Lopez-Villalobos N, Garrick DJ, Holmes CW, Blair HT and Spelman RJ (2000) Profitabilities of some mating systems for dairy herds in New Zealand. Journal of Dairy Science 83, 144-153.

Macdonald KA, Thorrold BS, Glassey CB, Holmes CW and Pryce JE (2005) Impact of farm management decision rules on the production and profit of different strains of Holstein-Friesian dairy cows. Proceedings of the New Zealand Society of Animal Production 65, 40-45.

Mancuso WA (2017) Evaluación y comparación de grupos genéticos lecheros en un sistema a pastoreo de la comarca lechera de Entre Ríos, Argentina (Doctoral thesis). University of Santiago de Compostela. Available at http://hdl.handle.net/10347/15513.

Nauta WJ (2001) Breeding strategies for organic animal production, an international discussion. In Hovi $\mathrm{M}$ and Baars $\mathrm{T}$ (eds), 4th NAHWOA Workshop. Network for Animal Health and Welfare in Organic Agriculture. Wageningen, The Netherlands: University of Reading (UK), pp. 4-13.

Nauta WJ, Baars T and Bovenhuis H (2006a) Converting to organic dairy farming: consequences for production, somatic cell scores and calving interval of first parity Holstein cows. Livestock Science 99, 185-195.

Nauta WJ, Veerkamp RF, Brascamp EW and Bovenhuis H (2006b) Genotype by environment interaction for milk production traits between organic and conventional dairy cattle production in The Netherlands. Journal of Dairy Science 89, 2729-2737.

Nauta WJ, Baars T, Saatkamp H, Weenink D and Roep D (2009) Farming strategies in organic dairy farming: effects on breeding goal and choice of breed. An explorative study. Livestock Science 121, 187-199.
Oltenacu PA and Broom DM (2010) The impact of genetic selection for increased milk yield on the welfare of dairy cattle. Animal Welfare 19, $39-49$.

Orjales I, López-Alonso M, Rodríguez-Bermúdez R, Rey-Crespo F, Villar A and Miranda $\mathbf{M}$ (2016) Is lack of antibiotic usage affecting udder health status of organic dairy cattle? Journal of Dairy Research 83, 464-467.

Patton J, Murphy JJ, O'Mara FP and Butler ST (2008) A comparison of energy balance and metabolic profiles of the New Zealand and North American strains of Holstein Friesian dairy cow. Animal: An International Journal of Animal Bioscience 2, 969-978.

Pedersen J and Christensen L (1989) Heterosis for milk production traits by crossing Red Danish, Finnish Ayrshire and Holstein-Friesian cattle. Livestock Production Science 23, 253-266.

Peeters A and Wezel A (2017) Agroecological principles and practices for grassbased farming systems. In Wezel A (ed), Agroecological Practices for Sustainable Agriculture. World Scientific, London, chapter 11, pp. 293-354.

Prendiville R, Pierce KM and Buckley F (2009) An evaluation of production efficiencies among lactating Holstein-Friesian, Jersey, and Jersey $\mathrm{x}$ Holstein-Friesian cows at pasture. Journal of Dairy Science 92, 6176-6185.

Prendiville R, Pierce KM, Delaby L and Buckley F (2011) Animal performance and production efficiences of Holstein-Friesian, Jersey and Jersey $\times$ Holstein-Friesian cows throughout lactation. Livestock Science 138, 25-33.

Pryce JE and Veerkamp RF (2001) The incorporation of fertility indices in genetic improvement programmes. BSAS Occasional Publication on Fertility in the High Production Dairy Cow, British Society of Animal Science 26, 227-250.

Pryce JE, Nielsen BL, Veerkamp RF and Simm G (1999) Genotype and feeding system effects and interactions for health and fertility traits in dairy cattle. Livestock Production Science 57, 193-201.

Rodríguez-Bermúdez R, López-Alonso M, Rey-Crespo F, Cortés L, Orjales I and Miranda M (2016) Raças de bovinos de leite em modo de produção biológico no norte de Espanha. In Marta-Costa AA, Tibério ML and Payan-Carreira R (eds), Raças Autóctones no Espaço Ibérico: Um recurso sustentável. Vila Real, Portugal: Universidade de Trás-os-Montes e Alto Douro, pp. 25-30.

Rodríguez-Bermúdez R, Miranda M, Orjales I, Rey-Crespo F, Muñoz N and López-Alonso M (2017) Holstein-Friesian milk performance in organic farming in North Spain: comparison with other systems and breeds. Spanish Journal of Agricultural Research 15, 1-10.

Roesch M, Doherr MG and Blum JW (2005) Performance of dairy cows on Swiss farms with organic and integrated production. Journal of Dairy Science 88, 2462-2475.

Röös E, Mie A, Wivstad M, Salomon E, Johansson B, Gunnarsson S, Wallenbeck A, Hoffmann R, Nilsson U, Sundberg $C$ and Watson CA (2018) Risks and opportunities of increasing yields in organic farming. A review. Agronomy for Sustainable Development 38, 14.

Rozzi P, Miglior F and Hand KJ (2007) A total merit selection index for Ontario organic dairy farmers. Journal of Dairy Science 90, 1584-1593.

Rushen J and Passillé A (2013) The importance of improving cow longevity. Cow Longevity Conference, pp. 3-21. Tumba (Sweden).

Slagboom M, Kargo M, Edwards D, Sørensen AC, Thomasen JR and Hjortø L (2016) Organic dairy farmers put more emphasis on production traits than conventional farmers. Journal of Dairy Science 99, 9845-9856.

Strandberg E and Roxström A (2000) Genetic parameters of functional and fertility determined length of productive life in Swedish dairy cattle. Animal Science 70, 383-389.

Swalve HH (2007) Crossbreeding in dairy cattle : international trends and results from crossbreeding data in Germany. Lohmann Information 42, 38-46.

Van der Ploeg JD (2003) The Virtual Farmer. Past, Present and Future of the Dutch Peasantry. Assen, The Netherlands: Royal Van Gorcum.

Van Diepen P, Mclean B and Frost D (2007) Livestock breeds and Organic farming systems. ADAS Pwllpeiran 1-39. Available at http://orgprints.org/ 10822/1/breeds07.pdf.

Villar A and López-Alonso M (2015) Udder health in organic dairy cattle in Northern Spain. Spanish Journal of Agricultural Research 13, e0503.

Vollema AR and Groen AF (1996) Genetic parameters of longevity traits of an upgrading population of dairy cattle. Journal of Dairy Science 79, 2261-2267. 